\title{
The Religious Imagination and Contemporary Public Theology
}

\section{Beneamin Mocan}

Faculty of Humanities and Social Sciences of the 'Aurel Vlaicu' University of Arad, Romania beni.mocan@yahoo.com

UDK: $141.78: 316.42(498): 27-1$ Review paper https://doi.org/10.32862/k.15.1.7

\section{Abstract}

The process of secularization, known as the process of the privatization of religion or its denial from the public square, is a heritage of Modernity. This reality had (and continues to have) important consequences for Christian theology. Hence, the renewal of Christian theology is urgent, and has a lot at stake, especially regarding the need for a renewed Christian message within contemporary society. Though public theology appeared as a normal consequence of the need for the renewal of Christian theology, this renewal is not necessarily present in many of its methods. The rigidity of both of its theological methods and language remains a problem for public theology. This article suggests that the new shift in anthropology should be taken into consideration when constructing a viable public theology nowadays. The category of "religious imagination" is of utmost importance since it takes into consideration the new definition of the human being, which is in line more with postmodernism than modernity. Thus, the article sketches the possible substantial contribution the religious imagination brings towards the revitalization of contemporary public theology. Moreover, the article mentions recent Romanian studies on the imagination, which stresses, even more, the richness hidden within it and its possible usage for the construction of a viable public theology.

Keywords: social and religious imagination, globalization, the new anthropology, Modernity, Postmodernism 


\section{Introduction}

The reality of globalization and the new public space must not and cannot be denied, as they have innumerable consequences for the entire global and local human existence. The technological and scientific advancement of the last decades has contributed and continues to do so massively to the birth and support of the global reality, which has major implications not only for the political, social, and cultural life of people but also for their religious life and their understanding of religion or belief and its usefulness in a globalized era. Does the Christian faith still have something to contribute and offer to such a complex society, which often defines itself as atheistic or even anti-theistic? Should it take into account these major transformations in contemporary society or not? If so, what are the realities that Christian theology must take into account and why? Does it have to adapt its theological discourse to the present times or can it use the same discourse because its truth transcends everyday realities and therefore responds to them regardless of the changes taking place in society?

Through this article, we aim to provide a brief answer to the above questions and others like them. Therefore, our approach will begin with the affirmation of the reality of globalization and the transformations that this phenomenon produces in human society. The study will continue to nuance the new anthropology and the need to renew contemporary theological discourse. It will be shown how "public theology" is being born out of the need for the renewal of Christian theology, however, it remains quite anchored in the methods of conventional theology, failing to respond satisfactorily to the needs of contemporary man and society. Therefore, we then propose the understanding of Christian theology or religious tradition as "imaginary," a category that is drawn with the help of local Romanian thinkers.

\section{The Reality of Globalization}

In Volume IV of his study, God and Globalization, Max Stackhouse sees the phenomenon of globalization as the most important challenge facing all of humanity, considering that the "complex dynamics of globalization" give rise to "a new and expanded public space," having considerable consequences for the Christian faith as a whole (Stackhouse 2007, 1). In a joint article, Os Guinness and David Wells also note the importance of the phenomenon of globalization in understanding the Christian faith and Christian theology as the vision of "the whole gospel for the whole world through the whole Church" has never been more real and yet more fiercely contested (Guinness and Wells 2010, 1). We consider their obser- 
vation to be extremely pertinent, the Christian Church in general and Christian theology, in particular, being quite reluctant to address with all responsibility and interest the reality of globalization and the important civilizational and epistemic changes it has triggered. Communicating the gospel or proclaiming it requires a deep knowledge of the realities of contemporary society, Guinness and Wells being aware of this. Moreover, they also give us a definition of globalization as a "multidimensional process, the decisive factor for its present expansion being not capitalism, but technology" (Guinness and Wells 2010, 2).

Because the technological phenomenon underlies globalization, affecting most (if not all) aspects of human life, Guinness and Wells speak of three major endeavors that Christian theology must consider regarding the phenomenon of globalization: (1) discernment of or understanding of the complex realities of society; (2) a careful assessment of the strengths and weaknesses of globalization; (3) involvement in society from this position (Guinness and Wells 2010, 2). Such an approach to the phenomenon of globalization is both responsible and courageous, which is being intimidated neither by the complexity of the problems that it brings forth nor by their multitude.

Stackhouse goes a step further and makes globalization a central issue for Christian theology:

[G]lobalization is best understood as a worldwide set of social, political, cultural, technological and ethical dynamics, influenced and legitimated by certain theological, ethical and ideological motifs, that are creating a worldwide civil society that stands beyond the capacity of any nation-state to control. It is influencing every local context, all peoples, all social institutions and the ecology of the earth itself. It is forming an alternative postmodernism, one that has elements of the fragmentation and the relativization of all previous securities, but that also is demanding the rediscovery of the universalistic principles of anthropology, spirituality, morality and law, refining distinctive purposes and forming new institutions that require common recognition. Thereby it is creating a newly contentious, comprehending public, one that modulates every regional and local context and yet is adapted into them and adopted by them in novel ways. In that way, it breaks down old barriers between people and creates new ways of interpreting and defining identities as it converts the world in unexpected directions (Stackhouse 2007, 8).

It is easy to see that the first major change that Stackhouse mentions is the anthropological one. If we refer to globalization as nothing more than the expression of a new anthropology, i.e., of a new definition of human beings, this has major implications for Christian theology. In other words, globalization uncovers the debate over the definition of humans between modernity and postmodernism, which has major implications for the way we do theology today. 


\section{A Revolution in Anthropology}

Modernity's anthropology is very well explained by the theologian James K. A. Smith who uses a suggestive expression referring to it: man as a "thinking things machine" (Smith 2010, 56). We speak, therefore, of the reductionist anthropology of Modernity, humans being understood through a "passionless objectivism" (Smith 2010, 59). For Modernity, its politico-economic project was the last priority, human beings being thus of secondary importance. Therefore, it was forced to violate the integrity of the human being, reducing it to a "thinking machine," being thus capable of using it in achieving its goals.

On the other hand, post-modern anthropology comes in stark contrast to modernist anthropology, launching harsh criticism against it. Therefore, humans are understood in a holistic sense, not being reduced exclusively to their ability to think. An excellent illustration of this reality is provided by David Brooks, an American public intellectual. In his book, The Social Animal, Brooks talks about the "inner mind" and its importance to the new anthropology. By "inner mind" Brooks refers to the realm of the human unconsciousness, i.e., "of emotions, intuitions, prejudices, passions, genetic predispositions, character traits and social norms" (Brooks 2011, x). He tells us the story of Harold and Erica, the two characters in the book, to illustrate certain post-modern anthropology: one that carefully considers the anthropological revolution in post-modernism, since his strong belief is that humanity is "in the midst of a revolution of human consciousness" (Brooks 2011, x). He builds on the discoveries of scientists who, in their quest to decipher the process by which contemporary society can achieve authentic human flourishing, argue that the key in achieving this goal is the understanding that people "are not primarily the product of conscious thinking" but they are "primarily the result of thinking that takes place below the level of consciousness" (Brooks 2011, x).

Timothy Wilson goes in the same direction when he says that the things we know about ourselves "cannot be known directly" even using a most careful introspection, and he notes that we are in a time when there is already a solid scientific basis on "the importance of subconscious thinking, feeling and motivation" (Wilson 2002, 5). This does not mean that reason is not important in human anthropology. Rather, we are talking about a paradigm shift, from a rationalized reductionist human anthropology to affective human anthropology which frameworks a holistic human being which assumes her affections as an organic part of the whole, i.e., all the complexity of the realm of the "inner mind" that we mentioned above. Wilson is therefore entitled to argue that "it is quite possible that the subconscious has a stronger impact on our behavior" than the conscious (Wilson 2002, 54). 
Even more fascinating about Brooks is that he includes human feelings in the realm of the subconscious and describes it as the place where the processes of meaning take place, being not "a deserted, mechanical place," but "an emotional and enchanted realm" (Brooks 2011, xi). If the anthropology of modernity has emphasized the centrality of reason, Post-modern anthropology emphasizes the centrality of human feelings, emotions, and passions. A certain remark by Brooks (2011, xi) still requires a little attention at this point in our approach:

If the outer mind highlights the power of the individual, the inner mind highlights the power of relationships, and the invisible bonds between people. If the outer mind hungers for status, money, and applause, the inner mind hungers for harmony and connection - those moments when self-consciousness fades away and a person is lost in a challenge, a cause, the love of another or the love of God.

We must not focus on how Brooks uses the antithesis "outer mind" and "inner mind," because we would lose sight of the central element of his remark. An understanding man rather in a postmodern sense, Brooks redeems human anthropology from the modernist reductionism applied to it. This is the central element of postmodern anthropology: man is more than reason, and therefore cannot be reduced to it. Besides, society, the creation of man, is not debauched, but is, as its creator, an enchanted realm, which cannot be explained exclusively rationally.

\section{Public Theology: The Renewal of Christian Theology?}

Public theology enters the global scene promising much. This can be easily deduced from the way it is defined. One of the best-known definitions is that offered by Duncan Forrester: public theology is "theology that seeks the welfare of the city before protecting the interests of the Church, or its property to preach the Gospel and celebrate the sacraments" (Forrester 2004, 6). Public theology is therefore committed to addressing the most acute socio-cultural problems of contemporary society. Its main purpose is therefore commendable. Hence, to fulfill its purpose, public theology must consider, as mentioned above, the paradigm shift of human anthropology.

Moreover, Forrester emphasizes that public theology uses the treasury of a certain religious tradition "to help in the building of a decent society, the restraint of evil, the curbing of violence, nation-building, and reconciliation in the public arena" (Forrester 2004, 6). Public theology therefore not only has a precise purpose, i.e., to adopt the agenda of society but also has a clear foundation: the treasure of a certain religious tradition. Any public theology is based on this treasure of faith. That being said, it is crucial in this point to emphasize that just as the purpose of public theology must be understood through the lens of the 
new human anthropology, so the foundation of public theology must be viewed through the same hermeneutical lens. Put differently, any religious tradition must be understood from the perspective of the paradigm shift of the new anthropology described above.

Even if public theology appeared on the global stage promising the renewal of the theological discourse and, consequently, the transformation of human society in search of the common good and human flourishing, it is imperative to note the fact that much of its approaches and methods remain deeply entrenched in the old reductionist-modernist anthropological paradigm. ${ }^{1}$

This reality is normal, because public theology, in our view, finds itself in a period of transition from the old methodologies of conventional Christian theology, of the Enlightenment, to methods that correspond to the paradigm shift we are referring to. That is why Stackhouse sees theology holistically, defining it from the perspective of the new anthropology, i.e., emphasizing the materiality of human existence, the social pluralism, and the idea of globalization, as we saw in his above-mentioned definition.

However, Stackhouse says he is somewhat dissatisfied with the methods used in building public theology: "The key problem is that today we do not have a profound public theology. [...] what we do not have is a reliable "science" by which we could assess the relative sense or nonsense [of public behaviors]" (Stackhouse 1987, 2). Stackhouse continues to express his dissatisfaction: "we do not have a common language for speaking of theological matters in the public domain, of what the ultimate reality behind human life in community entails" (Stackhouse $1987,2)$. Is it legitimate, then, to ask ourselves what would be the "common language" through which a public theology can be built for the common good and the good life? In other words, on what basis can a public theology be formulated that takes into account the paradigm shifts of post-modern anthropology?

\section{Religious Imagination and Public Theology}

The concept of "imagination" has been used for some time in the construction of public theology. For example, Scott Holland uses the notion of "religious imagi-

1 We mention here some contemporary public theologians who remain in the logic of the modernist-reductionist anthropological paradigm although, often in their works, they are aware of the paradigm shift discussed above. We mention here the following approaches: (1) the parochial approaches (e.g., Max Stackhouse, Robert Benne, Edward Foley, Daniel Benga, Chris Green or George Hunsberger); (2) sociological approaches (e.g., Raymond Pland and Theologia Socialis); (3) rhetorical approaches (e.g., Linell Caddy); transitional approaches - that take into consideration the changes brought about by both globalization and Postmodernism (e.g., David Tracy and Duncan Forrester). 
nation" when referring to human participation in the formation of culture, which is the decisive and indispensable component that facilitates human participation and, therefore, the cultural formation of society. According to Holland, the religious imagination is that creative human faculty, "a creative-complex polyphony," which facilitates the "formation of a social vision" by uniting three elements: theology, worship, and praxis (Holland 2005, 58-67).

Another, more widespread use of the concept of imaginary is the one proposed by Charles Taylor, i.e., the "social imaginary." In his understanding, the social imaginary presupposes "a much broader and deeper [framework] than the intellectual scheme people may entertain when they think about social reality in a disengaged mode" (Taylor 2004, 23). Taylor goes on to emphasize that the central aspect to which he refers has to do with "the way people imagine their social existence, how they fit together with others, how things go on between them and their fellows, the expectations that are normally met, and the deeper normative notions and images that underlie these expectations" (Taylor 2004, 23).

The category of "social imaginary" is useful mainly due to three things: (1) it is a common way in which people express their own "imaginary" using images, stories, and legends; (2) is universal, being shared by the entire existing public space; (3) is a "common understanding that makes possible common practices and a widely shared sense of legitimacy" (Taylor 2004, 23). The social imaginary, therefore, refers to that network of sensibilities, images, stories and precognitive feelings that functions as an a priori knowledge and is extremely important both for the new postmodern anthropology and for the analysis and construction of contemporary society and consequently, it is crucial to the construction of contemporary public theology.

Much could be written about other ways in which the category of the imaginary is used but we aim to emphasize the importance of taking it seriously for public theology and to also point out the significant contributions of some Romanian researchers to enrich the understanding of the category of "religious imagination" and to see how to properly use it for the construction of Public Theology. We want here to review, briefly, both the contributions of the Romanian historian Lucian Boia and those of the Centre for the Research of the Imaginary (CRI) - PHANTASMA within the Babeș-Bolyai University (UBB) from Cluj-Napoca, Romania.

In the first part of his book Toward a History of the Imaginary (ro., Pentru o istorie a imaginarului), Boia refers to the concept of the "imaginary" as "one of the safest ways to access the depths of the human spirit" (Boia 2000, 7). He rightly observes that the definition of the concept is problematic, often contradictory, and more confusing than elucidating its meaning. Therefore, Boia concludes that "the imaginary is an independent reality, having its own structures and its own dynamics" (Boia 2000, 14). Therefore, following Carl G. Jung, Boia proposes the 
structure of archetypes as constituent elements of the imaginary and speaks of eight archetypal structures that make up any imaginary: (1) the consciousness of a transcendent reality; (2) the soul, death, and the afterlife; (3) otherness or alterity; (4) unity or coherence; (5) the actualizing of the origins; (6) the deciphering the future; (7) the "escape" or refusal of the human condition; (8) the dialectic of opposites. The category of the imaginary elucidated by Boia's writings promises much and can be used, carefully, in the construction of an authentic contemporary public theology, i.e., which takes seriously the paradigm shift of the new anthropology already discussed. ${ }^{2}$

The Romanian school already enjoys an important imaginary research tradition through the CRI, within UBB, established in 2002, at the initiative of Corin Braga and other professors from UBB, during the same year being received in the network Centers de Recherches sur l'Imaginaire, a community that includes another 40 centers from around the world. In addition to many other studies undertaken by CRI, we mention here the recent publication, in five volumes, under the title "The Encyclopaedia of Romanian Imaginaries," extensive research that follows the defining components of the Romanian imaginary in literature, language, history, religion, and art. Notable is the volume on the religious imaginary, coordinated by Ioan Chirilă, which analyses the Romanian Christian religious imaginary starting with the Christianization of Dacia. We emphasize, above all, the introductory study signed by Ioan Chirilă that paints the conceptual delimitations of the category of the "religious imagination," which emphasizes once again the growing importance given to the imaginary today (Chirilă 2020, 13-27).

\section{Conclusion}

We sought to show through our study that the paradigm shift of post-modern anthropology has major implications for both the way we define ourselves and the way we understand our collective existence in society. This reality cannot be overlooked by theologians if we want the message of the Gospel to contribute to

2 Lucian Boia is well-known for his extensive use of the category of "imaginary" in the construction of history. His work consists of many volumes published both in Romania and in France, many of them being translated both in English and German. His extensive use of the category of "imaginary" abled him to tackle various issues as the end of the world, communism, nationalism, democracy etc. Moreover, the category of "imaginary" facilitated him with a particular understanding of the history of Romania, his publications in this direction being often vigorously criticized by other Romanian historians. We mention here several important studies regarding Boia's usage of the category of "imaginary": For a History of the Imaginary (2000); History and Myth in Romanian Conscience (1997); The Scientific Mythology of Communism (1999); The End of the World: an endless history (1999); Between Angel and Beast: the myth of the different man from Antiquity to the present day (2004); Democracy's myth (2003), etc. 
the common good and authentic human flourishing within contemporary society. We have seen that public theology, which arose from the need to renew theological discourse and as a reaction to the anthropological revolution, finds itself in a period of transition, trying to find those methods by which to make its voice heard in public space and to contribute for the betterment of society. To this end, we consider that understanding the category of the "imaginary" and its contribution to the renewal of theological discourse is urgent. Fortunately, there exist already serious studies in this direction, which will sooner or later have a strong impact on the way we theologize today.

\section{References}

Benga, Daniel. 2007. “Misiunea internă a Bisericii." INTER I 1-2: 113-122.

Benne, Robert. 1995. "The Paradoxical Vision: A Lutheran Nudge for Public Theology." Pro Ecclesia 4 (2): 212-223.

Boia, Lucian. 2000. Pentru o istorie a imaginarului. Bucharest: Humanitas.

Brooks, David. 2011. The Social Animal. New York: Random House.

Caddy, E. Linell. 1987. “A Model for Public Theology." Harward Theological Review 80 (2): 193-212.

Chirilă, Ioan. 2020. Imaginar religios. Volume IV. Bucharest: Polirom.

Forrester, Duncan. 2004. “The Scope of Public Theology." Studies in Christian Ethics 17 (2): 5-19.

Guinness, Os, and David Wells. 2010. "Global Gospel, Global Era: Christian discipleship and mission in the age of globalization". Presented at Lausanne Conference in Cape Town, on October 23, 2010. https://virtueonline.org/ cape-town-global-gospel-global-era (accessed May 13, 2020).

Holland, Scott. 2005. "Public Theology and Democracy." The Conrad Grebel Review 23 (5): 58-67.

Smith, James K. A. 2010. Thinking in Tongues: Pentecostal Contributions to Christian Philosophy. Grand Rapids: Eerdmans.

Stackhouse, Max. 1987. Public Theology and Political Economy: Christian Stewardship in Modern Society. Grand Rapids: Eerdmans. . 2007. God and Globalization, Volume 4: Globalization and Grace. New York: Continuum.

Taylor, Charles. 2004. Modern Social Imaginaries. Durham: University Press.

Wilson, Timothy. 2002. Strangers to Ourselves: Discovering the Adaptive Unconscious. Cambridge (Massachusetts): The Belknap Press. 


\section{Beneamin Mocan}

\section{Religijska imaginacija i suvremena javna teologija}

\section{Sažetak}

Proces sekularizacije, poznat i kao proces privatizacije religije, odnosno njezino uklanjanje iz javnog i društvenog života, predstavlja baštinu modernizma. Ova je realnost u značajnoj mjeri utjecala (i još uvijek utječe) na kršćansku teologiju. Zbog toga postoji hitna i značajna potreba za obnovom kršćanske teologije, posebno kad je riječ o potrebi za obnovljenom kršćanskom porukom u suvremenom društvu. Premda se činilo kako je javna teologija normalna posljedica potrebe za obnovom kršćanske teologije, ne znači da je obnova zapravo prisutna u mnogim njezinim metodama. Nefleksibilnost njezinih teoloških metoda i terminologije i dalje predstavljaju problem za javnu teologiju. U ovom članku sugeriramo da, pri konstruiranju održive javne teologije, valja uvažiti ovaj novi pomak u antropologiji. Kategorija „religijske imaginacije“ od vitalnog je značaja jer uvažava novu definiciju ljudskog bića koja je bliža postmodernizmu nego modernizmu. Zato u članku prikazujemo mogući značajan doprinos koji religijska imaginacija može pružiti u svrhu revitalizacije suvremene javne teologije. Nadalje, u članku spominjemo nedavna rumunjska istraživanja o ovoj temi u kojima se stavlja još veći naglasak na bogatstvo skriveno u njemu i njezinu moguću svrhu u konstruiranju održive javne teologije. 